\title{
Credit Rating Agency Downgrades and the Eurozone Sovereign Debt Crises
}

\author{
Christopher F Baum* (Boston College, DIW Berlin) \\ Margarita Karpava (MediaCom London) \\ Dorothea Schäfer (DIW Berlin, JIBS) \\ Andreas Stephan (JIBS, DIW Berlin, Ratio Institute Stockholm)
}

January 30, 2014

\begin{abstract}
This paper studies the impact of credit rating agency (CRA) downgrade announcements on the value of the Euro and the yields of French, Italian, German and Spanish long-term sovereign bonds during the culmination of the Eurozone debt crisis in 2011-2012. The employed GARCH models show that CRA downgrade announcements negatively affected the value of the Euro currency and also increased its volatility. Downgrading increased the yields of French, Italian and Spanish bonds but lowered the German bond's yields, although Germany's rating status was never touched by CRA. There is no evidence for Granger causality from bond yields to rating announcements. We infer from these findings that CRA announcements significantly influenced crisis-time capital allocation in the Eurozone. Their downgradings caused investors to rebalance their portfolios across member countries, out of ailing states' debt into more stable borrowers' securities.
\end{abstract}

Keywords: Credit Rating Agencies, Euro Crisis, Sovereign Debt, Euro Exchange Rate

JEL classification: G24, G01, G12, G14, E42, E43, E44, F31, F42, F65

${ }^{*}$ Corresponding author: Department of Economics, Boston College, 140 Commonwealth Avenue, Chestnut Hill MA 02135 USA. Email: baum@bc.edu. 


\section{Introduction}

In January 2012, the credit rating agency Standard \& Poor's (S\&P) downgraded the sovereign debt ratings of nine Eurozone countries, including France, which lost its previous AAA rating. S\&P also cut Austria's triple-A rating and relegated the sovereign debt of Portugal and Cyprus to junk status. The downgrading announcements received a great deal of public attention. Politicians in several Eurozone countries reacted by downplaying the role of rating announcements from credit rating agencies (CRAs) in an effort to ease the expected turbulence within the Eurozone.

The purpose of this paper is to examine the impact of CRA downgrade announcements on the Eurozone during the sovereign debt crisis of 2011-2012. Specifically, we study the role of rating announcements on exchange rate movements and government bond yields. We construct a database covering nearly 150 announcements of S\&P, Moody's, and Fitch during the sovereign debt crisis. The Euro began to depreciate in early 2009 when the large public deficits of several Euro countries became the topic of public debate. At the same time, the major credit rating agencies started downgrading Greek and Irish sovereign bonds due to these countries' government budget deficits. A series of negative watch and outlook revisions were announced by S\&P and Fitch, followed by massive downgrade announcements for Eurozone countries in early January 2012.

Financial investors, in particular banks and insurance companies, used to invest heavily in sovereign bonds of Eurozone countries. Downgrading may therefore not only increase the likelihood that other members of the currency union will be forced to bail out the ailing country but also weaken its own domestic banks. Both issues may pose a threat to the sustainability of their own government debt levels. Foreign investors may therefore interpret negative rating news on one country as a signal of worsening fundamentals in the Eurozone as a whole and subsequently withdraw their funds. This reaction may worsen the fundamental economic situation and trigger even further withdrawals. The rating announcement would then become a self-full-filling prophecy and trigger a currency crisis. Such a sequence of events was observed in the Asian crisis (Morris \& Shin 1998). Moreover, downgrades could initiate speculation against the Euro, placing even more pressure on its value.

Although some problems of the Eurozone are similar to the ones observed in the Asian crisis, there exists one decisive difference. Eurozone member states share a common currency but each 
country still possesses full fiscal sovereignty. This unique construction opens up the possibility to internally reallocate a Euro-dominated portfolio. Such an option was not available in the Asian crisis. If a CRA announcement triggered a portfolio rebalancing across member countries, from the debt of ailing states into more stable issuers' securities, a repricing of risks would occur within the Eurozone but the Euro exchange rate would be rather immune to CRA announcements.

There is anecdotal evidence that such portfolio reallocation effects indeed matter. For example, in recent months the Swedish National Bank (Riksbank) has shifted its Euro currency reserves from Spanish and Italian bonds to German bonds. ${ }^{1}$ However, so far, little effort has been made to systematically analyze and understand the link between downgradings of particular members, the repricing of risk within the Eurozone and the movements of the common currency. To date, most studies on the impact of credit rating announcements deal with stock and bond markets. To the best of our knowledge, we are the first to analyze the relationship between sovereign credit rating announcements, investors' portfolio decisions and the value of the common currency of sovereign member states during the culmination of the Eurozone crisis in 2011 and 2012.

Similar to the previous impact studies, this paper adopts an event-study methodology combined with an econometric GARCH model in order to estimate the impact of rating announcements by the three leading agencies (Standard \& Poor's, Moody's, and Fitch). We use three different models but the same econometric methodology: an exchange rate model and two CAPM models to explain sovereign bond yields for selected countries.

Our major finding is the following. CRA watchlist and outlook events have almost no significant impact on the value of the Euro currency. In contrast, sovereign downgrading has a statistically significant impact, as it leads to a depreciation of the Euro against the US dollar and other major currencies. Downgrading increases the excess yields of French, Italian and Spanish government bonds but at the same time lowers German bond yields. In some cases CRA announcements increase the volatilities of Euro exchange rates and sovereign bond yields, indicating higher market uncertainty around the events. We find no evidence for reverse Granger causality from bonds' yields to CRA announcements. Overall, these findings corroborate that investors rebalanced their portfolios

\footnotetext{
${ }^{1}$ See the Swedish economic newspaper Dagens Industri, June 4, 2013.
} 
across member countries, out of ailing states' debt into more stable securities. Consequently, CRA announcements may have distributional effects.

The remainder of the paper is organized as follows. The next section describes the background of the credit rating agency industry and reviews previous literature related to the impact of CRAs. In Section 3, we present a brief summary of rating announcements during the European sovereign debt crisis. Section 4 presents a comparison with the Asian financial crisis of 1997-1998. In Section 5, we develop the empirical methodology and Section 6 provides the results. Finally, Section 7 concludes.

\section{Background and Previous Research}

Credit rating agencies were created with the objective of solving information asymmetry problems in financial markets as they provide an assessment of a borrower's ability and willingness to repay its debt securities. The role of credit rating agencies in the global financial system as well as quality of their credit risk assessments has been widely debated. Credit rating agencies have often been criticized for violating their primary function of minimizing information uncertainty in financial markets. In line with this conclusion, Carlson \& Hale (2005), using a global games framework, find that the existence of credit rating agencies may threaten market stability as it increases the incidence of multiple equilibria. Bannier \& Tyrell (2005) report that a unique equilibrium can be restored by making the rating process more transparent, enabling market participants to independently assess quality and validity of credit ratings. The more accurate are credit rating announcements, the greater is the efficiency of investor decisions, and hence, is the market outcome.

Rating agencies assign a grade to the bond issuer according to the relative probability of default, which is measured by the country's political and economic fundamentals. The credit ratings industry is dominated by the three leading agencies: Standard \& Poor's (S\&P), Moody's Investors Service and Fitch Ratings. Even though the three credit rating agencies use different rating scales of measurement, there is a high degree of correspondence between them. A table with a corresponding definition of rating grades, assigned by each CRA, is listed in Table 1.

Credit ratings tend to differ among CRAs, which can be mainly attributed to different estimation 
methodologies and proxy variables considered in the analysis. S\&P focuses mostly on the forwardlooking probability of default. Moody's bases its rating decisions on the expected loss, which is a function of both the probability of default and the expected recovery rate. Finally, Fitch takes into consideration both the probability of default and the recovery rate (Elkhoury 2009).

Prior studies report that sovereign credit ratings are primarily affected by the following economic indicators: GDP per capita, GDP growth, public debt as a percentage of GDP, budget deficit as a percentage of GDP and inflation level within the country (Cantor \& Packer 1996). A history of sovereign default, the level of economic development and government effectiveness within the country have also been identified as important in determining sovereign credit ratings (Afonso et al. 2012). Information as to how CRAs assign weights to each variable they consider in assessment of the credit risk is not publically available.

The effects of sovereign credit ratings on debt and equity markets have been studied by many researchers. Brooks et al. (2004) report that rating downgrades negatively affect stock market returns. At the same time the dollar value of the domestic currency decreases. Kräussl (2005) shows that negative ratings significantly increase an index of speculative market pressure which consists of daily nominal exchange rate changes, daily short-term interest rate changes and daily stock market changes. In contrast, rating upgrades and positive outlooks show a weak or even insignificant impact. Kim \& Wu (2008) claim that long-term credit ratings support the development of financial markets in emerging economies.

Hooper et al. (2008) examine the impact of credit rating events on international financial markets using a database of 42 countries over the period 1995 to 2003. They provide evidence that rating upgrades significantly increased USD denominated stock market returns and decreased volatility. Downgrades show the corresponding contrary effect. However the market responses for both return and volatility are asymmetric and more pronounced for downgrades. A recent paper by Wu \& Treepongkaruna (2008) empirically tested the impact of sovereign credit rating news on volatility of stock returns and currency markets during the Asian financial crisis. Both market measures were found to be strongly affected by changes in sovereign credit ratings with currency markets being more responsive to credit rating news, while changes in sovereign outlooks had much stronger 
impact on stock price volatility than did actual rating announcements.

Several research papers also find strong contagion effects of watch and outlook changes on stock, bond and CDS markets of nearby countries. Hamilton \& Cantor (2004) and Alsati et al. (2005) find evidence that rating events such as outlooks and watchlist assignements increase the predictive power of sovereign credit rating announcements, as they shed light on which governments are likely to default on their debt or to be downgraded in the foreseen future.

\subsection{Credibility of CRA rating announcements}

The reliability of CRA announcements in times of crisis has often been questioned. Ferri \& Stiglitz (1999) report that prior to the Asian financial crisis, credit ratings were higher than economic fundamentals would suggest, while ex post ratings were much lower than the model predicted. This evidence suggests a procyclical rating behavior. Reinhart (2002) confirms that rating agencies lag behind the market. Following the markets with downgrading rather than leading it might accelerate the panic among investors, drive money out of the country and sovereign yield spreads up (Reisen \& von Maltzan 1999). Bhatia (2002) claims that failed ratings stem from CRAs' inclination towards ratings stability rather than accuracy of reported announcements. Mora (2006) reports indeed a considerable stickiness of ratings. Elkhoury (2009) also describes the assessment of the CRA as "tend[ing] to be sticky, lagging markets, and then overreact[ing] when they do change" (p. 1). Moreover, Ferri \& Stiglitz (1999) observe that in response to a past major rating failure CRAs tend to become overly conservative. This observation could suggest that CRA have downgraded Eurozone member states particularly aggressively in an effort to regain the reputation which was lost in the US sub-prime rating debacle. In the Asian crisis CRA downgrades posed a particular threat for the stability of ailing countries' currencies.

We take concerns of CRAs lagging behind the market into account in our analysis of the impact of sovereign rating news on currency movements and on a subsequent adjustment of bond portfolios, as we scrutinize the results for reverse causality effects. 


\subsection{Evidence on rating effects around the Eurozone crisis}

Since the bursting of the real estate bubble in the United States in the summer of 2007, European economies have been badly damaged by banking and sovereign debt crises. Most European member states suffered from rapidly increasing fiscal deficits, preventing them from meeting the Maastricht criteria for fiscal and monetary stability: public debt as a percentage of GDP below $60 \%$ and budget deficit as a percentage of GDP below 3\%. For example, public debt levels in Italy of $116.4 \%$ in $2009,119.3 \%$ in 2010 and $120.8 \%$, and in Greece of $129.7 \%$ in 2009, $148.3 \%$ in 2010 and $170.3 \%$ in 2011 far exceeded GDP in the corresponding years (see Figure 1). ${ }^{2}$ In addition to this, credit default swap (CDS) spreads experienced increased volatility during the financial crisis, resulting in a dramatic growth of CDS premia (see Figure 2). Deb et al. (2011) report that from January 2008 to June 2010 the premia increased $850 \%$ for France, $614 \%$ for Germany, 3364\% for Greece and $1394 \%$ for Spain.

Many European private banks have invested heavily in government bonds issued by the troubled countries, which now makes the return on these investments highly uncertain. At the end of the third quarter in 2011 German banks held 473.91 billion USD while French banks held 617.2 billion USD in troubled foreign debt of affected countries within the Eurozone. German and French banks were in particular invested in Italy and Spain. ${ }^{3}$ Therefore, even a partial default of one of those sizeable countries would have significantly hurt the banking industry in the European Union as well as its member states, since governments are usually required to support poorly capitalized banks.

Amidst this increasing uncertainty, on January 13, 2012 S\&P announced credit rating downgrades for nine EU member states, including France, which lost its "AAA" rating to "AA+", while Portugal and Cyprus were assigned junk-bond ratings. In addition to this, 14 countries within the EU were given negative outlooks, whereas only Germany's premium credit rating remained unaffected. On 27 February 2012 S\&P assigned "SD" grade to Greek sovereign bonds, thereby increasing the magnitude of investor risk aversion towards European financial markets.

\footnotetext{
${ }^{2}$ Eurostat 2012, http://epp.eurostat.ec.europa.eu/tgm/table.do?tab=table\&init $=1 \&$ language $=$ en $\&$ pcode $=$ tsdde $410 \&$ plugin $=1$.

${ }^{3}$ By the end of the first quarter of 2012, German banks held claims on Italian borrowers of 133 billion USD and on Spanish borrowers of 140 billion USD. French banks' exposure was 347 billion USD to Italy and 128 billion USD to Spain (Bank of International Settlements 2012, http://www.bis.org/statistics/consstats.htm).
} 
Existing research indicates the presence of statistically significant spillover effects of rating news from an event country to markets of non-event countries. Duggar et al. (2009) find evidence that sovereign defaults spread into other areas of corporate finance, leading to widespread corporate defaults. Arezki et al. (2011) report that rating downgrades to near-speculative grade for sovereigns are especially contagious across countries and financial markets. For example, a rating downgrade of Greece from "A-" to "BBB+" grade, as announced by Fitch on 8 December 2009, resulted in substantial spillover effects across members of the EMU including a 17 and 5 basis points increase in Greek and Irish CDS spreads respectively. Afonso et al. (2012) argue that rating downgrades of lower-rated countries have strong spillover effects on higher-rated sovereigns in the region, which is consistent with prior studies by Gande \& Parsley (2005) and Ismailescu \& Kazemi (2010). They also report statistically significant persistence effects of rating announcements: countries downgraded (upgraded) within the last month tend to have at least $0.5 \%$ higher (lower) sovereign bond yields for the next six months until the effect disappears. Interestingly CRA announcements by different agencies differ in their impact. Rating announcements by Moody's tend to have the strongest persistence effect of $1.5 \%$ higher bond yield spread for six months following a rating downgrade.

Alsakka \& ap Gwilym (2013) completed the first empirical study to test the direct impact of sovereign credit ratings on foreign exchange markets. Their event study results revealed that currency markets of higher-rated countries were more responsive to rating downgrades during the crisis period, while lower-rated countries' exchange rates are mostly affected in the pre-crisis period by sovereign ratings. Market reactions to credit rating changes and contagion effects were particularly strong during the crisis period of 2006-2010 compared to the pre-crisis period (2000-2006). Negative news from all three major agencies were reported to have an impact but Fitch triggered the strongest reactions. In contrast Ehrmann et al. (2013) found no effect of rating news on the Euro from October 1st, 2009 until November 30, 2011.

Our research is closely related to Afonso et al. (2012), Alsakka \& ap Gwilym (2013) and Ehrmann et al. (2013). However, since we are interested in the impact of CRA announcements on the single currency in times of crisis, we depart from these papers in a number of aspects. First, we concentrate on CRA announcements (unlike Ehrmann et al. 2013). Second, we consider only the Eurozone and 
exclusively analyze the period of the acute debt crisis (unlike Alsakka \& ap Gwilym 2013 and Afonso et al. 2012). Third, Afonso et al. (2012) focus on the impact of CRA announcements on spreads of sovereign bond yields over German bond yields for the EU countries. In contrast, we focus on excess bond yield from large Eurozone members since contagion effects from downgrades should be visible either in the exchange rate or in the large countries' yields.

\section{Development of debt ratios, ratings and exchange rates}

The most affected economies of the Eurozone debt crisis are Greece, Ireland, and Portugal along with Spain and Italy (GIPSI: see Figure 1). The CRAs were late with hinting at a possibly unsustainable debt level of Greece. The first negative credit rating announcements on Greece came to light only in 2009. S\&P published a negative watch announcement in the view of Greece's large budget deficit on January 9th, 2009. The actual rating downgrade from A to A- occurred shortly after on January 15th, 2009. Fitch released a negative outlook announcement on May 5th, 2009, followed by a rating downgrade from A to A- on October 22nd, 2009. Moody's was the last to react to the rising Greek budget deficit by putting Greece on a negative watch list on 29 October 2009, followed by a downgrade to A2 rating on 22 December 2009. In the 831 trading days from January 2009 through December 2012, a total of nearly 150 rating announcements were published by S\&P, Moody's and Fitch.

Standard and Poor's published 57 rating announcements, which include 35 rating downgrades, 22 negative watch lists and 28 negative outlook revisions. In addition, S\&P upgraded Greece twice in 2012. Fitch Ratings, in its turn, published 43 rating announcements, which include 29 actual downgrades, 10 watch negative reviews, 25 negative outlook revisions and one upgrade when Greece was assigned a B- rating on 13 March 2012. Moody's made 48 public announcements, which consist of 32 actual downgrades, 18 negative watch reviews and 30 outlook revisions. Figure 1b illustrates the downgrading activity using the example of S\&P. Table 2 summarizes the most significant announcements of the three CRAs during 2011-2012.

A different number of credit rating announcements published by each agency is not surprising as $\mathrm{S} \& \mathrm{P}$ is known for its focus on the accuracy of rating announcements in the short run, which gives 
rise to a higher frequency of public announcements over the time period under consideration. In contrast, Fitch Ratings and Moody's assign more value to the stability of sovereign credit ratings, therefore, the number of their rating events is considerably lower than that of S\&P.

The daily spot exchange rate movements reveal that the Euro depreciated significantly against the US dollar at the beginning of 2009 when a series of downgrades for Greek and Irish government bonds was announced. The pressure eased in mid-spring 2009 as a result of government assistance to financial institutions in the Eurozone. However, in November 2009 devaluation pressure took up again. At the beginning of June 2010 the Euro reached its lowest point within the period of the Eurozone debt crisis: 0.8335 Euros per USD according to the closing price on 4 June 2010. This period of extensive Euro depreciation occurred parallel to the rising public debt levels in Greece, Ireland, Portugal and Spain and the negative sovereign rating events published by each credit rating agency within this time frame.

The situation stabilized somewhat after Ireland and Greece were provided with a series of bailout packages from late 2010 through the first half of 2011. The stabilizing effect did not persist, though, as more countries of the EMU were becoming involved. Rising fears among investors of possible spillover effects to other countries within the Eurozone put a substantial strain on the Euro. Figure 5 shows that the bailout packages were, in fact, accompanied by increased downward pressure on the value of the common currency. The Euro lost value against the Japanese yen, the Swiss franc and the US dollar. Around the end of 2010 to the beginning of 2011, the common currency experienced a sudden slump in its value. At that time S\&P and Fitch assigned junk bond status to Greek government bonds. In December 2011, a series of negative watch and outlook revisions were announced by S\&P and Fitch, followed by massive downgrade announcements for Eurozone countries in January 2012. The Euro began depreciating again in the second quarter of 2011. In July 2011, Eurozone leaders decided in favor of a haircut of Greek bonds held by non-sovereign lenders. In the beginning of 2012, the Euro reached a further minimum. The haircut was executed in February 2012 accompanied by S\&P's SD (in default) rating for Greece. In the following month the Euro recovered to some degree, but downward pressure was renewed in early summer. When Moody's threatened to downgrade three European AAA-rated countries in July 2012, the Euro's 
value was again depressed, as the Euro lost about 10 percent of its value between January 2011 and July 2012. However, the overall change of the Euro's value in 2011 and 2012 was tiny: For example, against the US dollar, the Euro traded at the beginning of 2011 for 0.749 Euro per dollar. By the end of December 2012, the exchange rate was 0.758 Euro per dollar: a loss in value of only about one percent in two years.

\section{Currency movements during the Asian crisis of 1997-1998}

Table 3 shows the government debt ratios of those countries that were hit hardest during the Asian crisis. It is obvious that the ratios of Indonesia, South Korea, Malaysia and Thailand were very low compared with those of the GIPSI countries at the beginning of the Eurozone crisis. Even the debt ratio of the poorest country, Indonesia, was far below 100 percent in 1997. South Korea had the lowest debt burden in the region. The country's gross debt ratio was only about eight percent in 1996 and 11 percent in 1997.

Despite low debt/GDP ratios, investment capital began to flee the Asian countries in spring and summer 1997. The CRAs started downgrading Asian countries in October 1997 (Figure 3) through March 1998. The most affected country, Indonesia, ended up with a rating of CCC + (substantial risk). In contrast, in February 2012 Greece received the lowest possible rating grade SD (in default). Korea's rating grade in March 1998 was B (highly speculative). The second lowest rating grade among the GIPSI countries was BB (speculative) given in January 2012 by S\&P to Portugal.

The period of intense downgrading was much shorter in the Asian crisis than in the Eurozone crisis. However, the value of the domestic currencies of the affected countries in the region suffered much more than the Euro. The Indonesian rupiah lost more than 70 percent of its value against the US dollar in less than one year. Each of the other three regional currencies depreciated more than 30 percent. The rating agencies were considered to have contributed to a large extent to unnecessary withdrawals of funds from the region and the subsequent depreciation of regional currencies. For example, Radelet \& Sachs (1998) accused the major ratings agencies to have "belatedly downgraded countries in the region, triggering further withdrawals by creditors" (p. 27). 


\section{$5 \quad$ Empirical analysis}

\subsection{Event study methodology with GARCH models}

In this paper, we investigate the rating agencies' contribution to the trajectories of the Euro's value and that of selected government bond excess yields during the Eurozone crisis. We combine event study methodology with a GARCH model. The GARCH model has the advantage that it can quantify effects from the events both on the mean and on the volatility of exchange rates and bond yields. The events are defined as binary variables, where event days are coded as 1 and non-event days are coded as 0 . Because the effects from the event might not only occur on the day of the announcement, but also before and after the announcement, we define event windows including days before and after the event, as is common in the event study literature.

We formulate three different models for the purpose of our analysis. In the first model, we study the relationship between the Euro exchange rate and CRA events, considering a number of control variables. In the second model we formulate a CAPM approach to explain sovereign bond yields for the various countries. The third model is an extension of the second which also contains interaction effects of the event dummies with the bond betas.

Model I is formulated as follows:

$$
\Delta \ln \text { euro } \text { rate }_{t}=\beta_{0}+\beta_{1} \text { event }_{t}+\beta_{2} \Delta\left(i_{U S D}-i_{E U R}\right)_{t}+\beta_{3} \Delta \ln (v i x)_{t}+\varepsilon_{t},
$$

where $\Delta$ denotes a first differenced variable. The dependent variables which are tested with this model are the nominal effective trade-weighted nominal euro rate (NEER) and the Euro vs. Dollar spot rate. The NEER captures the value of the Euro against other major currencies. Higher values of the NEER indicate that the Euro has appreciated against other major currencies. We test the same model with the US dollar vs. Euro spot rate as a type of robustness check. As our major control variable we include the interest rate differential, $\left(i_{U S D}-i_{E U R}\right)$, in the equation. As we do not have a trade-weighted average of interest rates of the major Eurozone trading partners, we utilize the difference between 3-month money market rates (US LIBOR minus the EURIBOR rate) as a proxy. The purpose of this variable is to capture uncovered interest parity effects on the Euro 
rate. We expect that the interest rate differential to the US should be inversely related to the Euro rate: an increase in the interest rate differential leads to a depreciation of the Euro against the US dollar and in consequence also lowers the effective Euro rate.

Another control variable in Model I is the Chicago Board Options Exchange Volatility Index (VIX). This index measures the implied volatility of the S\&P500 stock index over a 30-day period. In our context the variable vix is used as a proxy for the level of investor uncertainty in US equity markets.

Model II is formulated to measure the effect of CRA announcements on government bond yields. We hypothesize that CRA downgrades trigger reallocation of capital within the Eurozone. As government bonds are a key asset in many institutional portfolios, geographic rebalancing of portfolios will affect the yields of these bonds. We expect that price changes of possible contagion effects from downgrades will be reflected in the bond yields of large Eurozone member countries. Specifically, we investigate the effect of ratings downgrades on the yields of France (FRA), German (GER), Italian (ITA), and Spanish (ESP) sovereign bonds.

The basis of Model II is a CAPM formulation which explains bond excess yields with the market excess yield. The strength and direction of this correlation is captured by the coefficient $\beta_{b o n d}$. The higher is $\beta_{b o n d}$, the higher the market risk of the bond, and the higher should be its expected excess yield. This is different from Afonso et al. (2012) who base their event study on the observed bond yield spreads between country specific bonds and German bonds. Accordingly, the equation is

$$
\Delta \underbrace{\left(\text { yield }_{t}-r_{t}^{f}\right)}_{\text {bond excess yield }}=\alpha_{0}+\alpha_{1} \text { event }_{t}+\beta_{\text {bond }} \underbrace{\left(\text { mktyield }-r_{t}^{f}\right)}_{\text {market excess yield }}+\alpha_{2} \Delta c d s_{t}+\alpha_{3} \Delta \ln \left(\text { vix } x_{t}\right)+\nu_{t},
$$

where $r^{f}$ denotes the risk-free yield, defined as the yield of AAA rated Eurozone sovereign bonds. We expect that $\alpha_{0}=0$, as bond yields should be only related to their systematic risk. The market yield, mktyield $d_{t}$, is defined as the average yield of all government bonds of the Eurozone with tenor of five years. The respective data are provided by the ECB. The variable $c d s$ is an index of credit default swaps for government bonds of the respective country. We use it as a proxy variable for the perceived investor risk for the government bonds from a specific country. We expect a positive relationship 
between $c d s$ and bond yield, since again higher systematic default risk should be compensated by higher expected yield. Furthermore, vix as a measure for overall uncertainty on the US stock market is also included. Given that Eurozone government bonds constitute alternative investment possibilities, we expect that an increase in uncertainty on US equity markets should increase the demand for Eurozone sovereign bonds. As a consequence excess yields of government bonds should fall.

In Model III, we propose that CRA events affect the relationship between market excess yields and bond excess yields, as well as the relationship between systematic default risk and bond excess yields. Thus, we conjecture in this model that CRA events have the effect of a moderator variable. We interact these variables with the event dummy variable:

$$
\begin{aligned}
\Delta\left(\text { yield }_{t}-r_{t}^{f}\right)= & \alpha_{0}+\alpha_{1} \text { event }_{t}+\beta_{\text {bond }}\left(\text { mktyield }_{t}-r_{t}^{f}\right) \\
& +\gamma_{\text {bond }}\left(\text { mktyield }_{t}-r_{t}^{f}\right) \times \text { event }_{t} \\
& +\alpha_{2} \Delta c d s_{t}+\alpha_{3} \Delta c d s_{t} \times \text { event }_{t}+\alpha_{4} \Delta \ln \left(\text { vix }_{t}\right)+\xi_{t} .
\end{aligned}
$$

In each model, we assume that the CRA event may not only affect the mean equation, but also the variance of the dependent variable (Bollerslev 1986). For instance, one could expect that during event times we observe a higher variance of the excess yield compared to non-event times. The simplest generalized autoregressive conditional heteroskedasticity model is $\operatorname{GARCH}(1,1)$. Diagnostic tests indicate the presence of GARCH effects after OLS estimation. One of the primary benefits of the GARCH specification is its parsimony in identifying the conditional variance. The GARCH formulation has also the advantage that variables can be specified that enter the variance specification collectively as multiplicative heteroskedasticity. The $\operatorname{GARCH}(1,1)$ conditional heteroscedasticity equation is specified as

$$
\sigma_{t}^{2}=\left(\gamma_{0}+\gamma_{1} \sigma_{t-1}^{2}+\lambda_{1} \varepsilon_{t-1}^{2}\right) \times\left(\theta_{1} \text { event }_{t}+\theta_{2} \ln v i x_{t}+\theta_{3} c d s_{t}\right)
$$

see Judge et al. (1985, p. 843). 
In principle we could have utilized more complicated models such as EGARCH (Nelson 1991) but these models often give rise to numerical estimation problems and non-convergence. Therefore we have decided to use the simplest GARCH model. Some models' residuals appear to be distributed with fatter tails than those of a normal distribution. To allow for this flexibility, a generalized error distribution (GED) model is specified (Bollerslev et al. 1994). The GED distribution includes the normal distribution as a special case when its estimated shape parameter is 2.0.

\section{Data Description and Results}

\subsection{Data sources}

Table 4 provides a description of the variables that are employed in the analysis. Most variables exhibit a unit root in levels, but are stationary in first differences. Credit rating announcements published by Standard and Poor's, Fitch Ratings, and Moody's were obtained from the official websites of each credit rating agency. We tested three types of events: watch, outlook and downgrade. We only report estimation results for downgrades in the following section, as watch and outlook events did not yield significant results.

The nominal effective Euro rate (NEER) for the Euro-17 countries vis-à-vis the group of trading partners was obtained from the ECB. ${ }^{4}$ The other data series: yields of five-year government bonds, the daily volatility index data from the CBOE (Chicago Board Options Exchange), three-month money market rates for the US dollar and the Euro and the CDS spreads were obtained from Thomson Reuters Datastream. The yields of Italian government bonds were obtained from the Italian central bank (Banca d'Italia). Figure 5 shows rating events and the development of the exchange rates. Figure 6 illustrates movements of the CBOE VIX and US-Euro interest rate differential. Figure 7 and Figure 2 show the evolution of excess yields of bonds and of CDS spreads respectively.

\footnotetext{
${ }^{4}$ The group of 20 trading partners consists of AU Australia, CA Canada, DK Denmark, HK China Hong Kong, JP Japan, NO Norway, SG Singapore, KR South Korea, SE Sweden, CH Switzerland, GB United Kingdom, US United States, BG Bulgaria, CZ Czech Republic, LV Latvia, LT Lithuania, HU Hungary, PL Poland, RO Romania and CN China.
} 


\subsection{Results}

Tables 5 and 6 provide summary statistics for the variables that are employed in the analysis. For Model I, Table 7 shows the effect of downgrade announcements on the NEER and the Euro-US dollar rate. The event window for the impact of the event on the Euro currency includes one day before the event and three days after it. The results show that downgrading reduces the nominal effective Euro rate (NEER). Thus, the Euro depreciated against major other currencies during the events. As a robustness check, we also test the effect of CRA downgrades on the US dollar / Euro spot rate and find basically the same results. The interest rate differential of US-Euro money market has the expected negative sign: a positive change leads to a depreciation of the Euro. The VIX also has the expected negative impact: in times of higher uncertainty in the US stock market, the demand for investments in the Eurozone increases and the Euro appreciates. More risk in the US stock market triggers higher volatility of the Euro against other currencies. The results also reveal that downgrade events increase risk in the currency markets, remarkably increasing the volatility of the Euro exchange rates. This is indicated by the significant coefficient for the respective variable event in the multiplicative heteroscedasticity equation.

For Model II, Table 8 displays the estimation results for government bond yields based on the CAPM formulation. The event window in the case of government bond yields is defined as the event day and the day after the event. Overall, the estimated $\beta_{\text {bond }}$ coefficients are significant and have the expected magnitude. Spain and Italy have $\beta_{\text {bond }}$ slightly above unity and thus exhibit a high correlation with the market risk of government bonds. On the other hand, France and Germany have much lower $\beta_{\text {bond }}$ values, with the German coefficient negative, implying that German expected excess yields fall if the market excess yields increase. For Spain, Italy and France, CRA events have a positive impact on the government bond yield, which means that during the event window, the prices for these bonds fell. On the other hand, we find evidence that CRA events had a negative impact on German yields, implying that German bonds gained in value. Notably, this effect is even significant if only the most significant events, as defined in Table 2, are used for the construction of the event dummy.

Regarding the impact of downgrading on the risk in the currency markets, we find that volatility 
increases only for French bonds, but not for the others. In contrast, the variable $c d s$ increases the volatility of government bond yields in each of the considered countries.

Finally, Model III's results, presented in Table 9, show that the effect of CRA events is not only of an additive nature, but that it also has an impact on $\beta_{\text {bond }}$. In the case of Spain and France, we see that $\beta_{\text {bond }}$ is significantly higher during the event window, implying that higher yields are also related to a higher market risk of these bonds during CRA events.

In sum, our empirical analysis reveals that contagion exists and is visible in the bond yields of large Eurozone members. The evidence confirms anecdotal evidence that CRA announcements triggered considerable portfolio rebalancing across member countries, from troubled states' sovereign debt into more stable sovereign issues. In contrast to the Asian crisis, downgrade events did not trigger a permanent currency depreciation. In fact, the Eurozone served as a kind of insurance mechanism against a severe currency crisis because it allows for internal reallocation of capital toward the liabilities of stronger sovereign borrowers. However, the protection against a severe currency crisis comes at a price. CRA announcements tend to accentuate fluctuations in both the Euro exchange rate and the price of sovereign bonds.

\subsection{Influence of the event window}

As a robustness check, we experiment with different definitions of the event window. It turns out that the length of the event window has a strong impact on the results. For the exchange rates, significance of the event on the dependent variables disappears if four days after the event are included in the event window. In the case of government bond yields the effect tapers off even faster. The event dummy becomes insignificant if more than one day after the event is included in the window. The impact on the volatility is similar. In the case of France the impact is also significant for longer definitions of the event window. However, in contrast to this finding, in the case of the Euro exchange rate, we do not find effects on the volatility for shorter event windows. 


\section{Conclusions}

This paper evaluates the effects of CRA announcements on the value of the Euro and the sovereign bond yields of major Eurozone countries. We combine event study methodology with a GARCH model to estimate the announcements' effect from events both on the level and on the volatility of our two main analysis variables. For sovereign bond yields, we formulate a CAPM-based model that links bond excess yields to market excess yields. We find that downgrade events reduce the value of the Euro and significantly affect sovereign bond yields. For Italian, French and Spanish sovereign bonds, we find that yields increase during event times, while German sovereign bond yields decrease. These findings are consistent with the observation that investors rebalanced their portfolios across member countries to reduce their exposure to riskier borrowers.

These results have important policy implications. The single currency has been an effective stabilizer against massive downward pressure triggered and fueled by repeated downgrading from rating agencies. In contrast to the Asian crisis, CRA announcements did not accelerate the movement of foreign funds out of the Eurozone and were unable to affect ailing countries' terms of trade in any permanent sense. The presence of stronger states within the Eurozone offered investors an elegant way to insulate their portfolios from the allegedly higher sovereign risk signalled by rating agencies' announcements. They could simply reallocate their funds from weaker to stronger states without changing the currency. However, the dampening of the adverse impact of downgrades on the ailing countries' terms of trade comes at a clear price. The reallocation of investors' funds has distributional effects, as it dramatically reduced Germany's cost of debt service while downrated countries have had to offer significantly better terms after downgrading events, and therefore bear considerably higher costs when issuing new debt. 


\section{References}

Afonso, A., Furceri, D. \& Gomes, P. (2012), 'Sovereign credit ratings and financial markets linkages: Application to european data', Journal of International Money and Finance 31(3), 606-638.

URL: http://ideas.repec.org/a/eee/jimfin/v31y2012i3p606-638.html

Alsakka, R. \& ap Gwilym, O. (2013), 'Rating agencies' signals during the european sovereign debt crisis: Market impact and spillovers', Journal of Economic Behavior \& Organization 85(C), 144162.

URL: http://ideas.repec.org/a/eee/jeborg/v85y2013icp144-162.html

Alsati, M., Katz, M., Leung, E. \& Vazza, D. (2005), Creditwatch and ratings outlooks: Valuable predictors of ratings behavior, Credit research, Standard and Poors.

Arezki, R., Candelon, B. \& Sy, A. (2011), Sovereign rating news and financial markets spillovers: Evidence from the European debt crisis, IMF Working Paper 11/68, International Monetary Fund. URL: http://www.imf.org/external/pubs/ft/wp/2011/wp1168.pdf

Bannier, C. \& Tyrell, M. (2005), Modelling the role of credit rating agencies - Do they spark off a virtuous circle?, Working Paper Series: Accounting and Finance 165, W. Goethe-University.

URL: https://opus.zbw-kiel.de/dspace/handle/10419/23425

Bhatia, A. V. (2002), Sovereign credit ratings methodology: An evaluation, IMF Working Paper 02/170, International Monetary Fund.

URL: http://ideas.repec.org/p/imf/imfwpa/02-170.html

Bollerslev, T. (1986), 'Generalized autoregressive conditional heteroskedasticity', Journal of econometrics 31, 307-327.

URL: http://www.sciencedirect.com/science/article/pii/0304407686900631

Bollerslev, T., Engle, R. F. \& Nelson, D. B. (1994), Chapter 49 arch models, Vol. 4 of Handbook of Econometrics, Elsevier, pp. $2959-3038$.

URL: http://www.sciencedirect.com/science/article/pii/S1573441205800182

Brooks, R., Faff, R. W., Hillier, D. \& Hillier, J. (2004), 'The national market impact of sovereign rating changes', Journal of Banking and Finance 28(1), 233-250.

URL: http://linkinghub.elsevier.com/retrieve/pii/S0378426602004065

Cantor, R. \& Packer, F. (1996), 'Determinants and Impact of Sovereign Credit Ratings', The Journal of Fixed Income 6(3), 76-91.

URL: http://www.iijournals.com/doi/abs/10.3905/jfi.1996.408185

Carlson, M. \& Hale, G. (2005), Courage to capital? A model of the effects of rating agencies on sovereign debt roll-over, Discussion Paper Series 1506, Cowles Foundation for Research in Economics, Yale University.

URL: http://papers.ssrn.com/sol3/papers.cfm?abstract_id=708581

Deb, P., Manning, M., Murphy, G., Penalver, A. \& Toth, A. (2011), Whither the credit ratings industry?, Financial Stability Paper 9, Bank of England. 
Duggar, E., Emery, K., Gates, D., Paulo, S., Lemay, Y. \& Cailleteau, P. (2009), Emerging market corporate and sub-sovereign defaults and sovereign crises: Perspectives on country risk, Technical report, Moody's Investors Service Global Credit Research.

URL: https://www.moodys.com/sites/products/DefaultResearch/2007400000573849.pdf

Ehrmann, M., Osbat, C., Stráský, J. \& Uusküla, L. (2013), The euro exchange rate during the european sovereign debt crisis - dancing to its own tune?, Working Paper Series 1532, European Central Bank.

Elkhoury, M. (2009), Credit rating agencies and their potential impact on developing countries, Compendium on debt sustainability and development, United Nations Conference on Trade and Development.

URL: http://unctad.org/en/docs/gdsddf20081_en.pdf\#page $=170$

Ferri, L.-G. \& Stiglitz, J. E. (1999), 'The Procyclical Role of Rating Agencies: Evidence from the East Asian Crisis', Economic Notes 28(3), 335-355.

URL: http://doi.wiley.com/10.1111/1468-0300.00016

Gande, A. \& Parsley, D. C. (2005), 'News spillovers in the sovereign debt market', Journal of Financial Economics 75(3), 691-734.

URL: http://linkinghub.elsevier.com/retrieve/pii/S0304405X04001576

Hamilton, D. \& Cantor, R. (2004), Rating transitions and defaults conditional on watchlist, outlook and rating history, Special commment, Moody's Investors Service Global Credit Research.

URL: http://papers.ssrn.com/sol3/papers.cfm?abstract_id=529823

Hooper, V., Hume, T. \& Kim, S.-J. (2008), 'Sovereign rating changes - do they provide new information for stock markets?', Economic Systems 32(2), 142-166.

URL: http://linkinghub.elsevier.com/retrieve/pii/S0939362508000034

Ismailescu, I. \& Kazemi, H. (2010), 'The reaction of emerging market credit default swap spreads to sovereign credit rating changes', Journal of Banking \&5 Finance 34(12), 2861-2873.

URL: http://linkinghub.elsevier.com/retrieve/pii/S0378426610001913

Judge, G. G., Griffiths, W. E., Hill, R. C., Lütkepohl, H. \& Lee, T.-C. (1985), The Theory and Practice of Econometrics, 2nd edn, Wiley.

Kim, S.-J. \& Wu, E. (2008), 'Sovereign credit ratings, capital flows and financial sector development in emerging markets', Emerging Markets Review 9(1), 17-39.

URL: http://linkinghub.elsevier.com/retrieve/pii/S1566014107000404

Kräussl, R. (2005), 'Do credit rating agencies add to the dynamics of emerging market crises?', Journal of Financial Stability 1(3), 355-385.

URL: http://linkinghub.elsevier.com/retrieve/pii/S1572308905000069

Mora, N. (2006), 'Sovereign credit ratings: Guilty beyond reasonable doubt?', Journal of Banking E Finance 30(7), 2041-2062.

URL: http://linkinghub.elsevier.com/retrieve/pii/S0378426605001354 
Morris, S. \& Shin, H. S. (1998), 'Unique equilibrium in a model of self-fulfilling currency attacks', American Economic Review 88(3), 587-97.

Nelson, D. B. (1991), 'Conditional Heteroskedasticity in Asset Returns: A New Approach', Econometrica 59(2), 347-370.

URL: http://www.jstor.org/stable/2938260

Radelet, S. \& Sachs, J. D. (1998), 'The east asian financial crisis: Diagnosis, remedies, prospects', Brookings Papers on Economic Activity 29(1), 1-90.

Reinhart, C. M. (2002), 'Default, currency crises, and sovereign credit ratings', World Bank Economic Review 16(2), 151-170.

URL: http://ideas.repec.org/a/oup/wbecrv/v16y2002i2p151-170.html

Reisen, H. \& von Maltzan, J. (1999), 'Boom and Bust and Sovereign Ratings', International Finance 2(2), 273-293.

URL: http://doi.wiley.com/10.1111/1468-2362.00028

Wu, E. \& Treepongkaruna, S. (2008), Realizing the impacts of sovereign ratings on stock and currency markets, Conference paper, The European Financial Management Association.

URL: http://www.efmaefm.org/OEFMAMEETINGS/EFMA ANNUAL MEETINGS/2008athens/Treepongkaruna.pdf 
Table 1: CRA Rating Grades and Definitions

\begin{tabular}{l|l|l|l}
\hline Moody's & S\&P & Fitch & Definition \\
\hline Aaa & AAA & AAA & Prime \\
Aa1 & AA + & AA + & High grade \\
Aa2 & AA & AA & \\
Aa3 & AA- & AA- & \\
A1 & A + & A + & Upper medium grade \\
A2 & A & A & \\
A3 & A- & A- & \\
Baa1 & BBB + & BBB + & Lower medium grade \\
Baa2 & BBB & BBB & \\
Baa3 & BBB- & BBB- & \\
Ba1 & BB + & BB + & Non-investment grade \\
Ba2 & BB & BB & speculative \\
Ba3 & BB- & BB- & \\
B1 & B + & B + & Highly speculative \\
B2 & B & B & \\
B3 & B- & B- & \\
Caa1 & CCC + & CCC & Substantial risks \\
Caa2 & CCC & & \\
Caa3 & CCC- & & \\
Ca & CC & & Extremely speculative \\
C & C & & \\
& SD & DDD & In default \\
& & DD & \\
& & D & \\
& & &
\end{tabular}


Figure 1: Debt ratios and rating movements of selected Eurozone countries

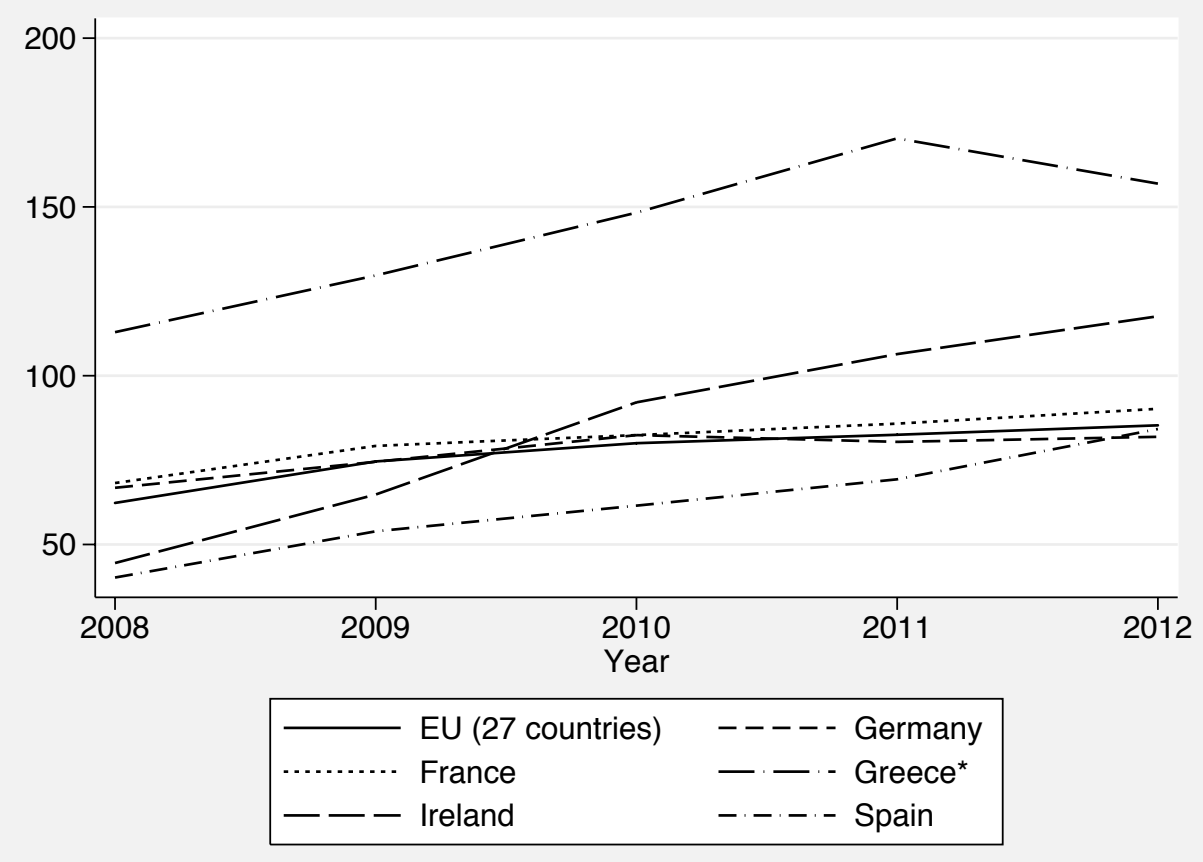

(a) Debt to GDP Ratios, 2008-2012

*The haircut on Greek debt in early 2012 reduced the debt ratio by the end of 2012 to about 158 percent of GDP.

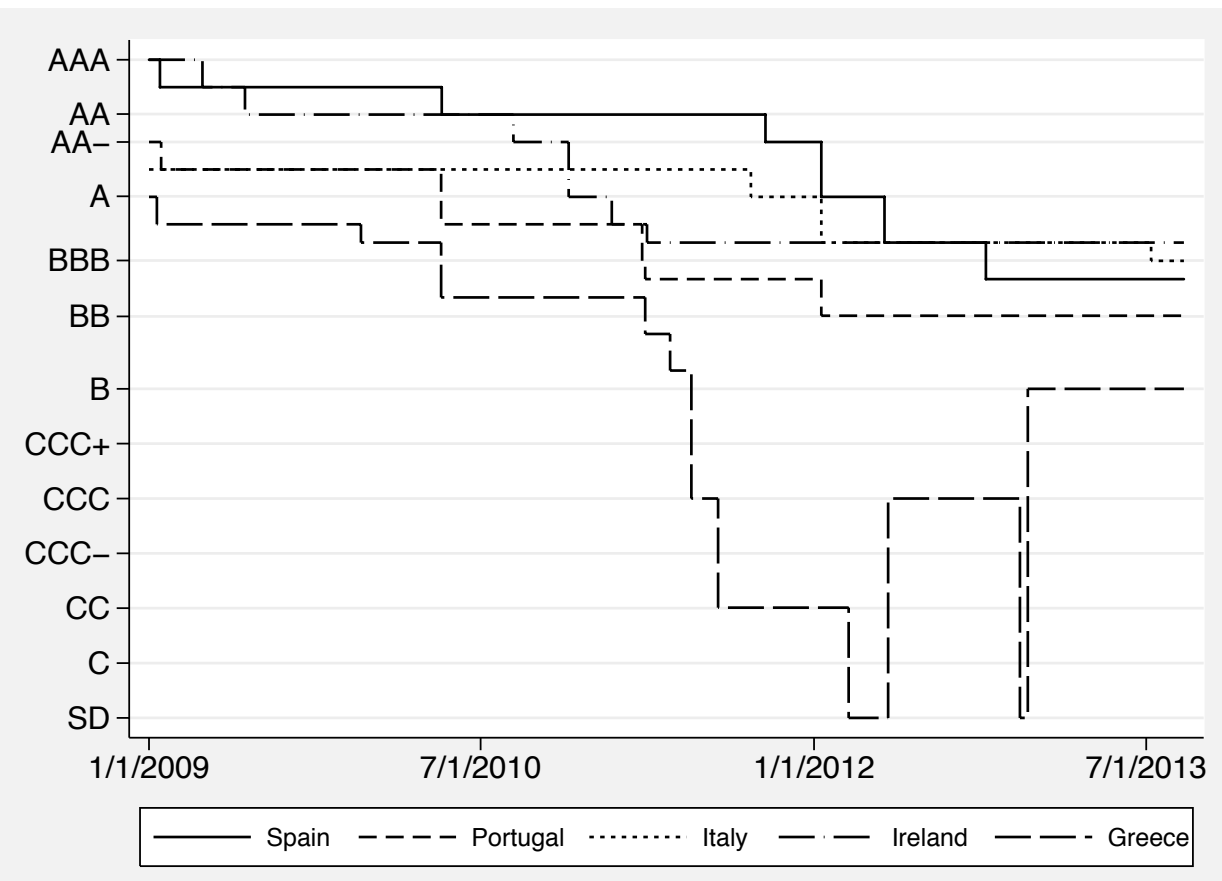

(b) GIPSI countries: Rating activities of S\&P 
Figure 2: Credit Default Swaps and CRA Downgrade Announcements, 2009-2012

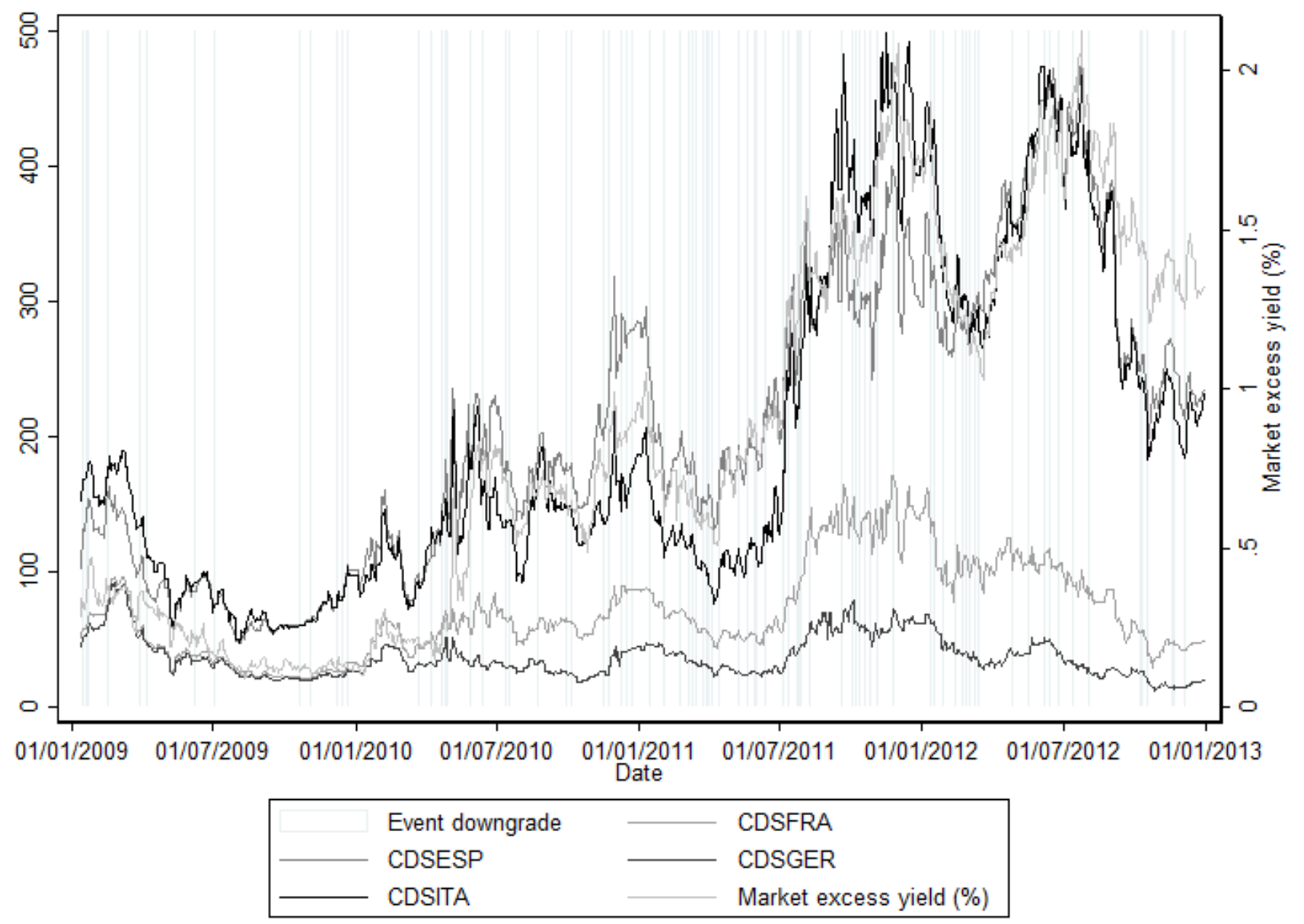

Sources : Datastream, Events: S\&P, Fitch or Moody's Downgrade of Eurozone States' Sovereign Debt 
Figure 3: Downgrades of the most affected countries in the Asian crisis

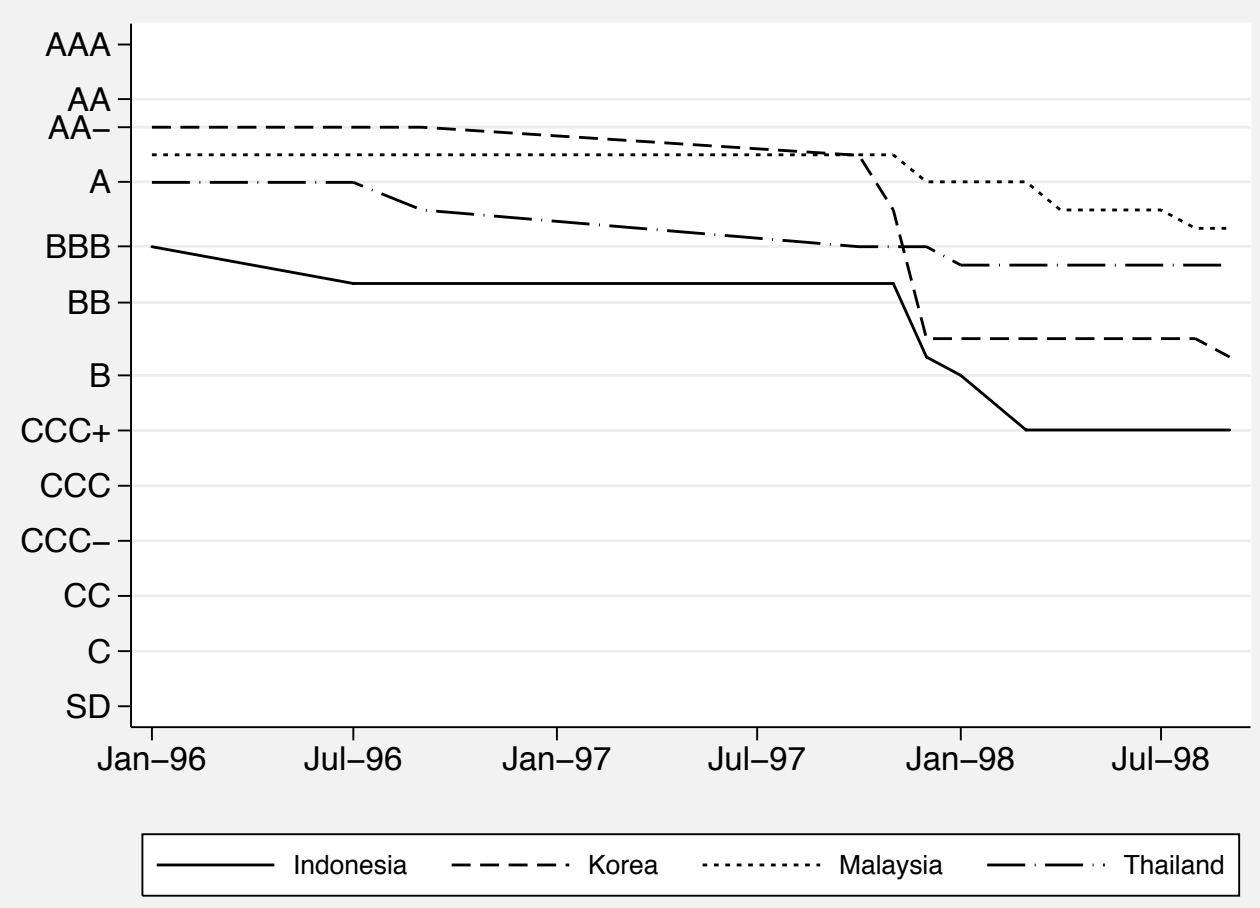

Figure 4: Currency movements of Asian crisis countries, 1997-1998

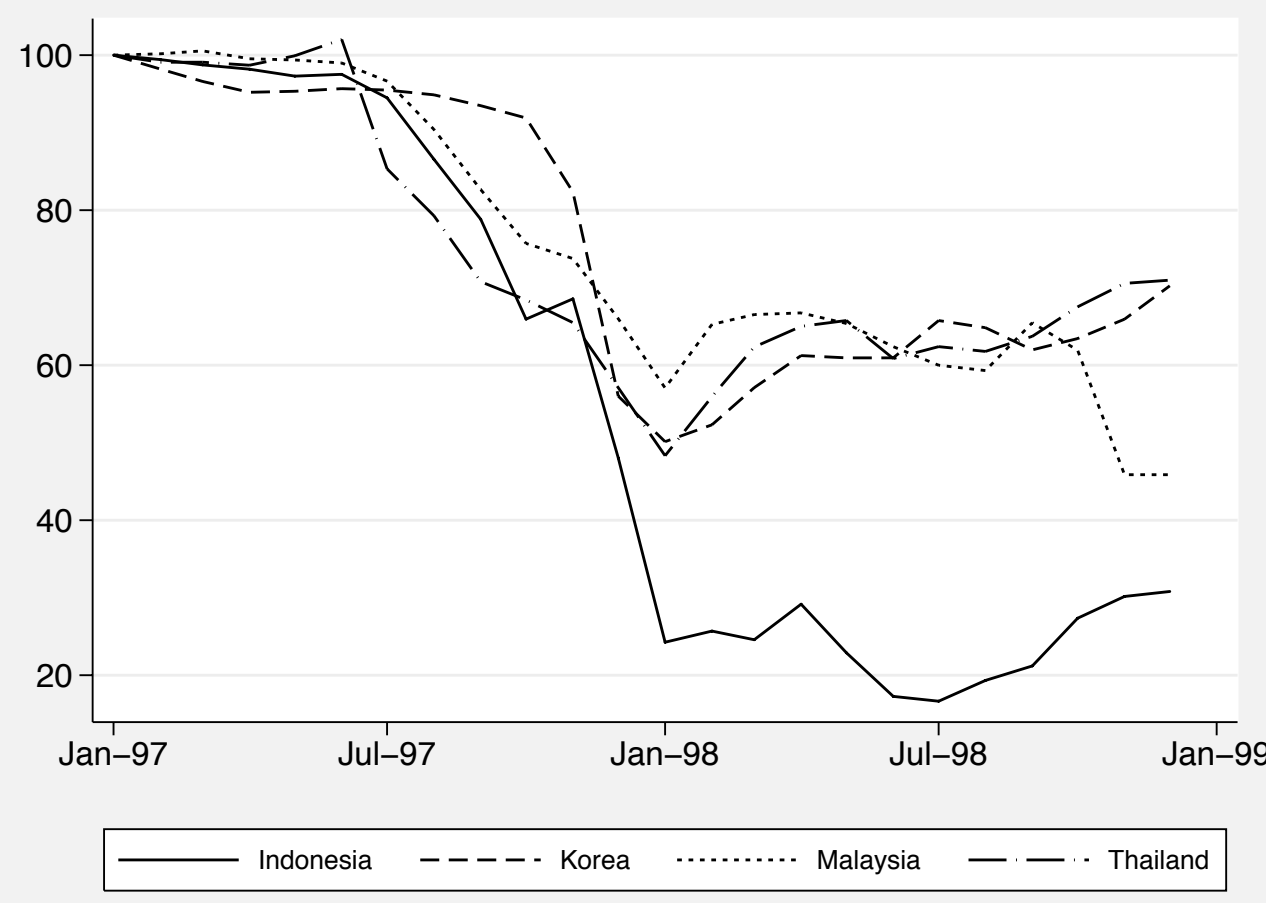


Figure 5: Exchange Rates and CRA Downgrade Announcements, 2010-2012

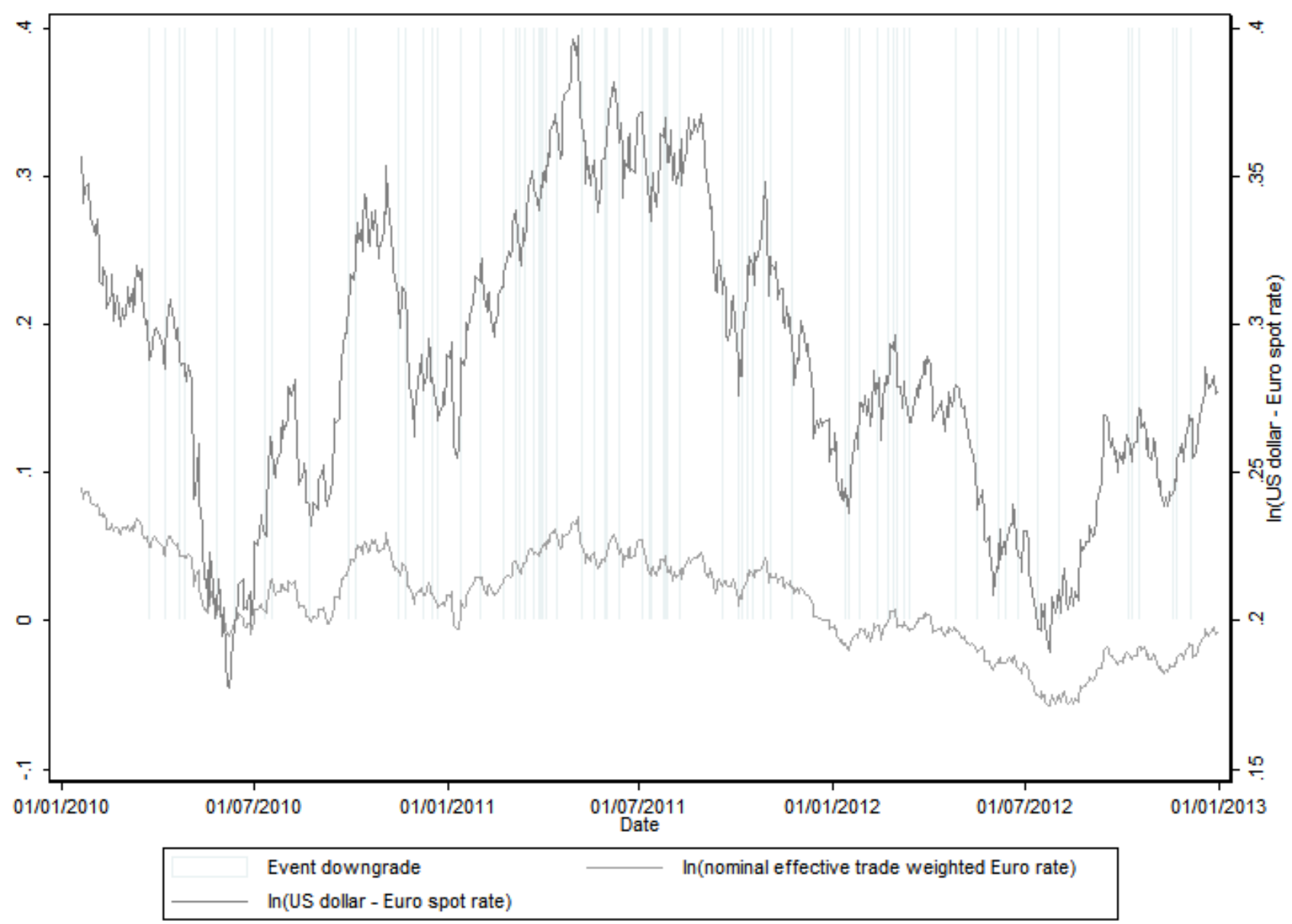

Sources : Datastream, Events: S\&P, Fitch or Moody's Downgrade of Eurozone States' Sovereign Debt 
Figure 6: US/Euro Interest Rate Differential, CBOE VIX and CRA Downgrade Announcements, 2010-2012

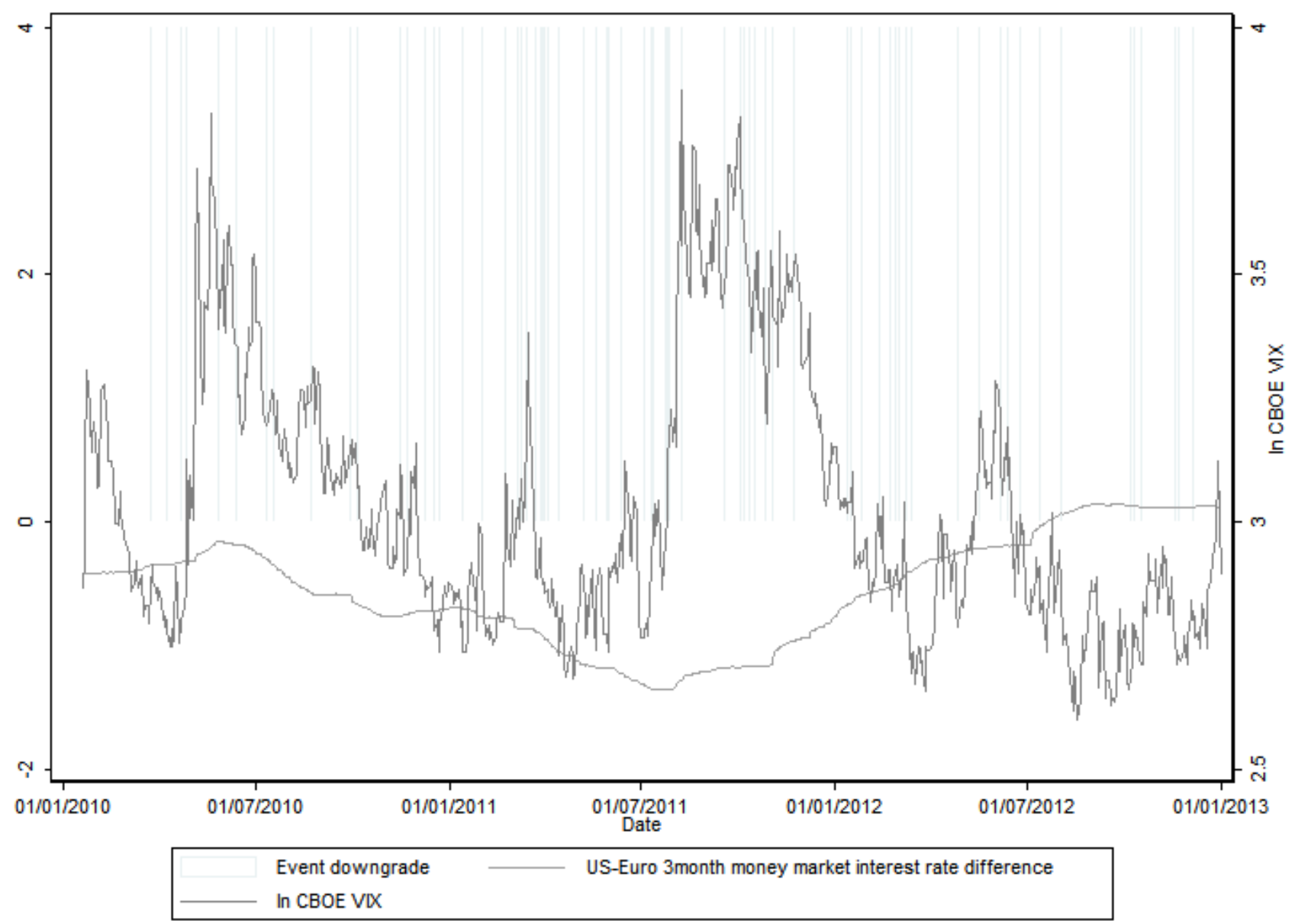

Sources : Datastream, Events: S\&P, Fitch or Moody's Downgrade of Eurozone States' Sovereign Debt 
Figure 7: Five-year Sovereign Bond Excess Yields and CRA Downgrade Announcements, 2009-2012

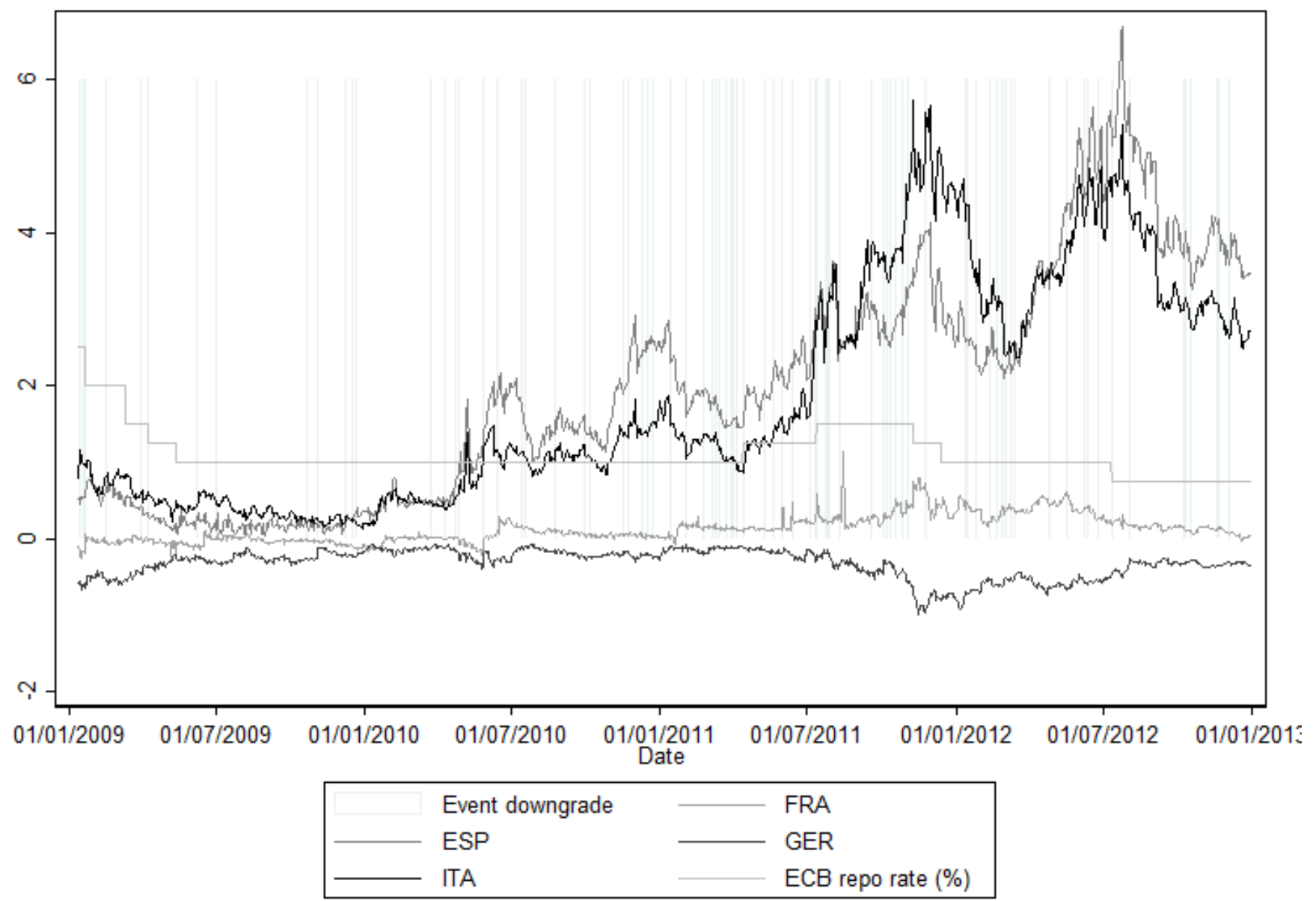

Sources : Datastream, Events: S\&P, Fitch or Moody's Downgrade of Eurozone States' Sovereign Debt 
Table 2: Significant Sovereign Debt Rating Events, 2011-2012

\begin{tabular}{|c|c|c|}
\hline Source & Date & Event \\
\hline Standard and Poor's (S\&P) & 5 December 2011 & $\begin{array}{l}15 \text { Eurozone member states put on } \\
\text { credit watch, France among them }\end{array}$ \\
\hline $\mathrm{S} \& \mathrm{P}$ & 13 January 2012 & $\begin{array}{l}16 \text { Eurozone countries downgraded, } \\
\text { France among them }\end{array}$ \\
\hline $\mathrm{S} \& \mathrm{P}$ & 4 December 2012 & $\begin{array}{l}\text { threat to downgrade all Eurozone } \\
\text { (negative watch) }\end{array}$ \\
\hline Moody's & 18 October 2011 & threat to downgrade France \\
\hline Moody's & 13 February 2012 & $\begin{array}{l}\text { Downgrading of six Eurozone countries } \\
\text { (Italy, Malta, Portugal, Slovakia, } \\
\text { Slovenia and Spain) }\end{array}$ \\
\hline Moody's & 24 July 2012 & $\begin{array}{l}\text { Threat to downgrade } 3 \text { AAA-rated economies } \\
\text { the next } 18 \text { months (Germany, the Netherlands } \\
\text { and Luxembourg) due } \\
\text { to developments in Spain and Greece }\end{array}$ \\
\hline Moody's & 19 Nov 2012 & Downgrading of France \\
\hline Fitch's Ratings & 19 December 2011 & $\begin{array}{l}\text { Threat to downgrade France and } \\
\text { other Eurozone } \\
\text { countries (Belgium, Cyprus, Ireland, } \\
\text { Slovenia and Spain) }\end{array}$ \\
\hline Fitch's Ratings & 27 January 2012 & $\begin{array}{l}\text { Downgrading of five Eurozone countries } \\
\text { (Italy, Belgium, Slovenia and Cyprus) } \\
\text { while Ireland gets a negative outlook. }\end{array}$ \\
\hline Fitch's Ratings & 11 May 2012 & $\begin{array}{l}\text { Fitch puts all Eurozone states } \\
\text { negative watch if Greece exits. }\end{array}$ \\
\hline
\end{tabular}


Table 3: Gross debt to GDP of Asian countries and currency depreciation (\%), 1996-1999

\begin{tabular}{|c|c|c|c|c|c|}
\hline & \multicolumn{4}{|c|}{ Debt ratio } & US Dollar to Domestic currency: Loss \\
\hline Country & 1996 & 1997 & 1998 & 1999 & Jan 1997-Dec 1998 \\
\hline Indonesia & 24.61 & 33.97 & 60.14 & 66.96 & -69.2 \\
\hline South Korea & 8.19 & 10.74 & 15.82 & 15.04 & -29.8 \\
\hline Malaysia & 33.99 & 30.69 & 35.01 & 35.85 & -54.1 \\
\hline Thailand & 3.81 & 6.93 & 15.03 & 21.33 & -29.0 \\
\hline
\end{tabular}

Notes: Source debt ratio data: Thomson Reuters Datastream (Oxford Economics).

Source exchange rate data: World Bank Global Economic Monitor

Exchange rate: Loss in USD/LCU. For example, the same amount of Indonesian rupiah that bought USD 1 in Jan 1997 was worth only about USD 0.31 two years later.

Table 4: Variable Descriptions

\begin{tabular}{lll}
\hline Variable & Description & Source \\
\hline FRA & France 5 year government bond yield & Datastream \\
ESP & Spain 5 year government bond yield & Datastream \\
GER & Germany 5 year government bond yield & Datastream \\
ITA & Italy 5 year government bond yield & Banca d'Italia \\
NEER & nominal effective Euro rate for Euro area-17 countries & ECB \\
& vis-à-vis the EER-20 group of trading partners, trade weighted & \\
spot $_{U S D / E U R}$ & USD-Euro spot rate & ECB \\
event & event downgrade announcement (S\&P, Fitch or Moody's) & Authors' collection \\
$v i x$ & near-term volatility conveyed by S\&P 500 & Datastream \\
& stock index option prices (CBOE). & \\
$\Delta\left(i_{U S D}-i_{E U R}\right)$ & difference of 3-month money market rates & Datastream \\
& between US and Euro & \\
$r_{f}$ & credit default swaps on government bonds: ITA, GER, FRA and ESP & Datastream \\
market yield & government 5-year bond par yield of triple AAA rated Eurozone bonds & ECB \\
\hline
\end{tabular}

Table 5: Summary Statistics, Model I

\begin{tabular}{lccccc}
\hline \multicolumn{1}{c}{ Variable } & Mean & Std. Dev. & Skew. & Min. & Max. \\
\hline event & 0.427 & 0.495 & 0.296 & 0 & 1 \\
$\Delta \ln (\mathrm{NEER})$ & $-5.40 \mathrm{E}-05$ & $3.30 \mathrm{E}-03$ & -0.445 & -0.014 & $8.60 \mathrm{E}-03$ \\
$\Delta \ln \left(\operatorname{spot}_{U S D / E U R}\right)$ & $-4.20 \mathrm{E}-05$ & $6.20 \mathrm{E}-03$ & -0.406 & -0.027 & 0.016 \\
$\Delta\left(i_{U S D}-i_{E U R}\right)$ & $1.70 \mathrm{E}-03$ & $8.90 \mathrm{E}-03$ & 3.57 & -0.064 & 0.094 \\
$\Delta \ln ($ vix $)$ & $3.30 \mathrm{E}-06$ & 0.073 & 0.786 & -0.314 & 0.405 \\
\hline Notes: daily frequency, sample period from 1.1.2011 to 31.12.2012 $(499$ obs $)$, \\
$\Delta$ denotes first difference, $x(t)-x(t-1)$, event: downgrade, window $=[-1,+3]$
\end{tabular}


Table 6: Summary Statistics, Model II

\begin{tabular}{lccccc}
\hline \multicolumn{1}{c}{ Variable } & Mean & Std. Dev. & Skew. & Min. & Max. \\
\hline event & 0.204 & 0.404 & 1.47 & 0 & 1 \\
$\Delta\left(\right.$ ESP- $\left.r_{f}\right)$ & $2.60 \mathrm{E}-03$ & 0.169 & -0.459 & -0.899 & 0.717 \\
$\Delta\left(\right.$ ITA $\left.-r_{f}\right)$ & $2.80 \mathrm{E}-03$ & 0.163 & -0.343 & -0.933 & 0.633 \\
$\Delta\left(\right.$ FRA $\left.-r_{f}\right)$ & $2.40 \mathrm{E}-04$ & 0.079 & 0.042 & -0.925 & 0.914 \\
$\Delta\left(\right.$ GER $\left.-r_{f}\right)$ & $-4.30 \mathrm{E}-04$ & 0.034 & 0.183 & -0.155 & 0.171 \\
$\Delta\left(\right.$ market yield $\left.-r_{f}\right)$ & $1.10 \mathrm{E}-03$ & 0.052 & -0.212 & -0.225 & 0.167 \\
$\Delta$ CDS ESP & 0.046 & 13.6 & -0.051 & -60 & 61.3 \\
$\Delta$ CDS ITA & 0.172 & 14.8 & 0.365 & -51.3 & 89.4 \\
$\Delta$ CDS FRA & -0.061 & 5.92 & -0.125 & -29.5 & 25.5 \\
$\Delta$ CDS GER & -0.054 & 2.58 & 0.6 & -13.2 & 19 \\
\hline
\end{tabular}

Notes: daily frequency, sample period from 1.1.2011 to 31.12 .2012 (499 obs), $\Delta$ denotes first difference, $x(t)-x(t-1)$, event: downgrade, window $=[0,+1]$ 
Table 7: Model I Results for Euro Exchange Rates

\begin{tabular}{|c|c|c|}
\hline & $\Delta \ln (\mathrm{NEER})$ & $\Delta \ln \left(\operatorname{spot}_{\$ / \tilde{A} \hat{r} \hat{A} £ \AA S S}\right)$ \\
\hline $\begin{array}{l}\text { Mean equation } \\
\text { event }\end{array}$ & $\begin{array}{c}-0.0006^{* *} \\
(0.0003)\end{array}$ & $\begin{array}{c}-0.0009^{*} \\
(0.0005)\end{array}$ \\
\hline$\Delta \ln (v i x)$ & $\begin{array}{c}-0.0093^{* * *} \\
(0.0020)\end{array}$ & $\begin{array}{c}-0.0230^{* * *} \\
(0.0036)\end{array}$ \\
\hline$\Delta\left(i_{U S D}-i_{E U R}\right)$ & $\begin{array}{c}-0.0582^{* * *} \\
(0.0129)\end{array}$ & $\begin{array}{c}-0.1098^{* * *} \\
(0.0300)\end{array}$ \\
\hline constant & $\begin{array}{c}0.0004^{* *} \\
(0.0002)\end{array}$ & $\begin{array}{c}0.0006^{* *} \\
(0.0003)\end{array}$ \\
\hline $\operatorname{AR}(1)$ & $\begin{array}{l}-0.0659 \\
(0.0467)\end{array}$ & $\begin{array}{c}-0.1064^{* *} \\
(0.0463)\end{array}$ \\
\hline $\begin{array}{l}\text { Variance equation } \\
\text { event }\end{array}$ & $\begin{array}{c}0.4095 * * * \\
(0.1386)\end{array}$ & $\begin{array}{c}0.4676^{* * *} \\
(0.1347)\end{array}$ \\
\hline $\ln (v i x)$ & $\begin{array}{c}0.4662^{* *} \\
(0.2267)\end{array}$ & $\begin{array}{c}0.7246^{* * * *} \\
(0.2218)\end{array}$ \\
\hline constant & $\begin{array}{c}-12.8874^{* * *} \\
(0.7879)\end{array}$ & $\begin{array}{c}-12.5058^{* * *} \\
(0.7250)\end{array}$ \\
\hline $\mathrm{ARCH}(1)$ & $\begin{array}{c}0.0085 \\
(0.0364)\end{array}$ & $\begin{array}{c}0.0064 \\
(0.0389)\end{array}$ \\
\hline $\operatorname{GARCH}(1)$ & $\begin{array}{l}-0.2799 \\
(0.3810)\end{array}$ & $\begin{array}{l}-0.2495 \\
(0.3225)\end{array}$ \\
\hline Chi2(df) & $45.6(4)$ & $59.8(4)$ \\
\hline p-value & 0.00000 & 0.00000 \\
\hline Log-Likelihood & 2174.6 & 1873.9 \\
\hline Obs & 499 & 499 \\
\hline
\end{tabular}


Table 8: Model II Results for Sovereign Bond Yields

\begin{tabular}{|c|c|c|c|c|}
\hline & $\Delta \mathrm{ESP}$ & $\Delta \mathrm{ITA}$ & $\Delta \mathrm{FRA}$ & $\triangle \mathrm{GER}$ \\
\hline $\begin{array}{l}\text { Mean equation } \\
\text { event }\end{array}$ & $\begin{array}{l}0.0157^{*} \\
(0.0086)\end{array}$ & $\begin{array}{l}0.0109^{*} \\
(0.0063)\end{array}$ & $\begin{array}{c}0.0083^{* *} \\
(0.0038)\end{array}$ & $\begin{array}{c}-0.0069^{* *} \\
(0.0032)\end{array}$ \\
\hline mkt excess yield & $\begin{array}{c}1.1616^{* * *} \\
(0.0956)\end{array}$ & $\begin{array}{c}1.0983^{* * *} \\
(0.0691)\end{array}$ & $\begin{array}{c}0.1291^{* * *} \\
(0.0283)\end{array}$ & $\begin{array}{c}-0.0869^{* * *} \\
(0.0213)\end{array}$ \\
\hline$\Delta c d s$ & $\begin{array}{c}0.0046^{* * *} \\
(0.0004)\end{array}$ & $\begin{array}{c}0.0048^{* * *} \\
(0.0003)\end{array}$ & $\begin{array}{c}0.0004 \\
(0.0003)\end{array}$ & $\begin{array}{c}-0.0022^{* * *} \\
(0.0006)\end{array}$ \\
\hline$\Delta \ln (v i x)$ & $\begin{array}{l}-0.0404 \\
(0.0540)\end{array}$ & $\begin{array}{c}0.0159 \\
(0.0451)\end{array}$ & $\begin{array}{l}-0.0089 \\
(0.0259)\end{array}$ & $\begin{array}{c}-0.0657^{* * * *} \\
(0.0171)\end{array}$ \\
\hline constant & $\begin{array}{l}-0.0032 \\
(0.0042)\end{array}$ & $\begin{array}{l}-0.0024 \\
(0.0030)\end{array}$ & $\begin{array}{c}0.0001 \\
(0.0012)\end{array}$ & $\begin{array}{c}0.0000 \\
(0.0009)\end{array}$ \\
\hline $\operatorname{AR}(1)$ & $\begin{array}{c}-0.2140^{* * *} \\
(0.0431) \\
\end{array}$ & $\begin{array}{c}-0.1192^{* *} \\
(0.0484) \\
\end{array}$ & $\begin{array}{c}-0.3734^{* * *} \\
(0.0397) \\
\end{array}$ & $\begin{array}{c}-0.2553^{* * *} \\
(0.0495) \\
\end{array}$ \\
\hline $\begin{array}{l}\text { Variance equation } \\
\text { event }\end{array}$ & $\begin{array}{l}-0.7299 \\
(0.6958)\end{array}$ & $\begin{array}{l}-0.3560 \\
(1.0136)\end{array}$ & $\begin{array}{c}1.2367^{* * *} \\
(0.1539)\end{array}$ & $\begin{array}{l}-0.5564 \\
(0.8345)\end{array}$ \\
\hline$c d s$ & $\begin{array}{c}0.0092^{* * *} \\
(0.0013)\end{array}$ & $\begin{array}{c}0.0074^{* * *} \\
(0.0017)\end{array}$ & $\begin{array}{c}0.0041 \\
(0.0036)\end{array}$ & $\begin{array}{c}0.0471^{* * *} \\
(0.0132)\end{array}$ \\
\hline $\ln (v i x)$ & $\begin{array}{l}-0.0881 \\
(0.3181)\end{array}$ & $\begin{array}{c}0.0979 \\
(0.7902)\end{array}$ & $\begin{array}{c}2.6515^{* * * *} \\
(0.4194)\end{array}$ & $\begin{array}{c}0.2966 \\
(0.6932)\end{array}$ \\
\hline constant & $\begin{array}{c}-8.1944^{* * *} \\
(1.1776)\end{array}$ & $\begin{array}{c}-9.4604^{* * *} \\
(2.1879)\end{array}$ & $\begin{array}{c}-15.2387^{* * *} \\
(0.9890)\end{array}$ & $\begin{array}{c}-10.9075^{* * *} \\
(1.7494)\end{array}$ \\
\hline $\operatorname{ARCH}(1)$ & $\begin{array}{c}0.0304 \\
(0.0424)\end{array}$ & $\begin{array}{c}0.1707^{* * *} \\
(0.0655)\end{array}$ & $\begin{array}{c}0.9788^{* * *} \\
(0.1420)\end{array}$ & $\begin{array}{r}0.1557^{* *} \\
(0.0673)\end{array}$ \\
\hline $\operatorname{GARCH}(1)$ & $\begin{array}{c}0.7447^{* * *} \\
(0.1441)\end{array}$ & $\begin{array}{c}0.7263^{* * *} \\
(0.0875)\end{array}$ & $\begin{array}{c}-0.0458^{* *} \\
(0.0203)\end{array}$ & $\begin{array}{c}0.5030^{* * *} \\
(0.1924)\end{array}$ \\
\hline GED shape & $\begin{array}{c}1.5576^{* * *} \\
(0.1413)\end{array}$ & $\begin{array}{c}1.5624^{* * *} \\
(0.1287)\end{array}$ & & $\begin{array}{l}1.6935^{*} \\
(0.1722)\end{array}$ \\
\hline constant & $\begin{array}{c}0.4351^{* * *} \\
(0.0880) \\
\end{array}$ & $\begin{array}{c}0.4462^{* * *} \\
(0.0821) \\
\end{array}$ & & $\begin{array}{c}0.5268^{* * *} \\
(0.1017)\end{array}$ \\
\hline Chi2(df) & $718.2(5)$ & $1422.4(5)$ & $129.4(5)$ & $110.0(5)$ \\
\hline p-value & 0.00000 & 0.00000 & 0.00000 & 0.00000 \\
\hline Log-Likelihood & 395.9 & 533.5 & 819.4 & 1086.5 \\
\hline Obs & 499 & 499 & 499 & 499 \\
\hline
\end{tabular}

Notes: Standard errors in parentheses, ${ }^{* * *} \mathrm{p}<0.01,{ }^{* *} \mathrm{p}<0.05,{ }^{*} \mathrm{p}<0.1$

event window $=[0,+1]$, GER bonds: only significant events (see Table 1$)[0,+2]$

Test GED shape parameter, H0: GED shape=2 (normal distr) 
Table 9: Model III Results for Sovereign Bond Yields with Event Interactions

\begin{tabular}{|c|c|c|c|c|}
\hline & $\begin{array}{l}\Delta \mathrm{ESP} \\
(1)\end{array}$ & $\begin{array}{c}\Delta \mathrm{ITA} \\
(1)\end{array}$ & $\begin{array}{c}\Delta \mathrm{FRA} \\
(1)\end{array}$ & $\begin{array}{c}\Delta \text { GER } \\
\text { (1) }\end{array}$ \\
\hline \multicolumn{5}{|l|}{ Mean equation } \\
\hline event & $\begin{array}{c}0.0203^{* *} \\
(0.0093)\end{array}$ & $\begin{array}{c}0.0078 \\
(0.0064)\end{array}$ & $\begin{array}{l}0.0088^{*} \\
(0.0050)\end{array}$ & $\begin{array}{c}-0.0082^{* *} \\
(0.0038)\end{array}$ \\
\hline mkt excess yield & $\begin{array}{c}1.1203^{* * *} \\
(0.0966)\end{array}$ & $\begin{array}{c}1.1026^{* * *} \\
(0.0708)\end{array}$ & $\begin{array}{c}0.1179^{* * *} \\
(0.0300)\end{array}$ & $\begin{array}{c}-0.0875^{* * *} \\
(0.0213)\end{array}$ \\
\hline mkt excess yield $\times$ event & $\begin{array}{c}0.0796 \\
(0.0539)\end{array}$ & $\begin{array}{c}0.0008 \\
(0.0320)\end{array}$ & $\begin{array}{c}0.0323^{* *} \\
(0.0126)\end{array}$ & $\begin{array}{c}0.0021 \\
(0.0023)\end{array}$ \\
\hline$\Delta c d s$ & $\begin{array}{c}0.0048^{* * *} \\
(0.0004)\end{array}$ & $\begin{array}{c}0.0048^{* * *} \\
(0.0003)\end{array}$ & $\begin{array}{c}0.0007^{* *} \\
(0.0003)\end{array}$ & $\begin{array}{c}-0.0022^{* * *} \\
(0.0006)\end{array}$ \\
\hline$\Delta c d s \times$ event & $\begin{array}{l}-0.0004 \\
(0.0003)\end{array}$ & $\begin{array}{c}0.0000 \\
(0.0002)\end{array}$ & $\begin{array}{c}-0.0005^{* * *} \\
(0.0002)\end{array}$ & $\begin{array}{c}0.0001 \\
(0.0002)\end{array}$ \\
\hline$\Delta \ln (v i x)$ & $\begin{array}{l}-0.0411 \\
(0.0545)\end{array}$ & $\begin{array}{c}0.0187 \\
(0.0458)\end{array}$ & $\begin{array}{l}-0.0132 \\
(0.0207)\end{array}$ & $\begin{array}{c}-0.0644^{* * *} \\
(0.0171)\end{array}$ \\
\hline constant & $\begin{array}{l}-0.0044 \\
(0.0044)\end{array}$ & $\begin{array}{l}-0.0016 \\
(0.0031)\end{array}$ & $\begin{array}{l}-0.0003 \\
(0.0011)\end{array}$ & $\begin{array}{c}0.0001 \\
(0.0009)\end{array}$ \\
\hline $\operatorname{AR}(1)$ & $\begin{array}{c}-0.2130^{* * *} \\
(0.0437)\end{array}$ & $\begin{array}{c}-0.1228 * * \\
(0.0486)\end{array}$ & $\begin{array}{c}-0.3545^{* * *} \\
(0.0421)\end{array}$ & $\begin{array}{c}-0.2591^{* * *} \\
(0.0495)\end{array}$ \\
\hline $\begin{array}{l}\text { Variance equation } \\
\text { event }\end{array}$ & $\begin{array}{l}-0.8671 \\
(2.0983)\end{array}$ & $\begin{array}{l}-2.4819 \\
(2.6426)\end{array}$ & $\begin{array}{c}3.9941^{* * *} \\
(0.4143)\end{array}$ & $\begin{array}{c}0.1381 \\
(2.1582)\end{array}$ \\
\hline$c d s$ & $\begin{array}{c}0.0091^{* * *} \\
(0.0016)\end{array}$ & $\begin{array}{c}0.0059^{* * *} \\
(0.0021)\end{array}$ & $\begin{array}{c}0.0164^{* * *} \\
(0.0043)\end{array}$ & $\begin{array}{c}0.0494^{* * *} \\
(0.0139)\end{array}$ \\
\hline$c d s \times$ event & $\begin{array}{c}0.0002 \\
(0.0077)\end{array}$ & $\begin{array}{c}0.0081 \\
(0.0074)\end{array}$ & $\begin{array}{c}-0.0301^{* * *} \\
(0.0050)\end{array}$ & $\begin{array}{l}-0.0188 \\
(0.0556)\end{array}$ \\
\hline $\ln (v i x)$ & $\begin{array}{l}-0.0487 \\
(0.3153)\end{array}$ & $\begin{array}{c}0.0141 \\
(0.7809)\end{array}$ & $\begin{array}{c}1.4135^{* * *} \\
(0.4700)\end{array}$ & $\begin{array}{c}0.2081 \\
(0.7107)\end{array}$ \\
\hline constant & $\begin{array}{c}-8.2548^{* * *} \\
(1.2095)\end{array}$ & $\begin{array}{c}-8.7195^{* * *} \\
(2.2040)\end{array}$ & $\begin{array}{c}-12.8045^{* * *} \\
(1.1146)\end{array}$ & $\begin{array}{c}-10.7494^{* * *} \\
(1.7476)\end{array}$ \\
\hline $\mathrm{ARCH}(1)$ & $\begin{array}{c}0.0295 \\
(0.0427)\end{array}$ & $\begin{array}{c}0.1769^{* * * *} \\
(0.0681)\end{array}$ & $\begin{array}{c}0.8550^{* * *} \\
(0.1266)\end{array}$ & $\begin{array}{c}0.1602^{* *} \\
(0.0686)\end{array}$ \\
\hline $\operatorname{GARCH}(1)$ & $\begin{array}{c}0.7439^{* * * *} \\
(0.1441)\end{array}$ & $\begin{array}{c}0.7086^{* * * *} \\
(0.0912)\end{array}$ & $\begin{array}{l}-0.0283 \\
(0.0191)\end{array}$ & $\begin{array}{c}0.5049^{* * *} \\
(0.1859)\end{array}$ \\
\hline GED shape & $\begin{array}{c}1.5576^{* * *} \\
(0.1413)\end{array}$ & $\begin{array}{c}1.5651^{* * * *} \\
(0.1241)\end{array}$ & & $\begin{array}{l}1.6970^{*} \\
(0.1727)\end{array}$ \\
\hline constant & $\begin{array}{c}0.4431^{* * * *} \\
(0.0907)\end{array}$ & $\begin{array}{c}0.4480^{* * * *} \\
(0.0793)\end{array}$ & & $\begin{array}{c}0.5289^{* * *} \\
(0.1018)\end{array}$ \\
\hline Chi2(df) & $728.8(7)$ & $1443.3(7)$ & $133.3(7)$ & $112.2(7)$ \\
\hline p-value & 0.00000 & 0.00000 & 0.00000 & 0.00000 \\
\hline Log-Likelihood & 397.2 & 534.8 & 848.9 & 1087.4 \\
\hline Obs & 499 & 499 & 499 & 499 \\
\hline
\end{tabular}

Notes: Standard errors in parentheses, ${ }^{* * *} \mathrm{p}<0.01,{ }^{* *} \mathrm{p}<0.05,{ }^{*} \mathrm{p}<0.1$

event window $=[0,+1]$, GER bonds: only significant events (see Table 1$)[0,+2]$

Test GED shape parameter, H0: GED shape $=2$ (normal distr) 